\title{
PENGARUH PENDAPATAN TERHADAP POLA KONSUMSI PETANI PADI PADA KELOMPOK TANI NGUDI REJEKI DI DESA WONOREJO KECAMATAN KENCONG KABUPATEN JEMBER
}

\author{
Lujeng Shahadatus Safia ${ }^{1}$, Bambang Suyadi ${ }^{1}$, Hety Mustika Ani ${ }^{1}$ \\ ${ }^{1}$ Program Studi Pendidikan Ekonomi, Fakultas Keguruan dan Ilmu Pendidikan, Universitas Jember \\ e-mail: lujeng_safia@yahoo.com
}

\begin{abstract}
Abstrak
Penelitian ini bertujuan untuk mengetahui pengaruh pendapatan terhadap pola konsumsi petani padi pada kelompok tani Ngudi Rejeki Desa Wonorejo Kecamatan Kencong Kabupaten Jember. Penelitian ini merupakan penelitian kuantitatif karena dalam prosedur dan analisisnya peneliti menggunakan metode statistik berupa angka-angka. Metode pengumpulan data yang digunakan terdiri dari metode angket, observasi, wawancara dan dokumen. Analisis data yang akan digunakan yaitu analisis inferensial yang terdiri dari analisis regresi linier sederhana, analisis varian garis regresi, uji $\mathrm{F}$, efektivitas garis regresi/koefisien determinasi dan standart error of estimate. Hasil penelitian menunjukkan variabel pendapatan berpengaruh signifikan terhadap pola konsumsi petani padi pada kelompok tani Ngudi Rejeki di Desa Wonorejo Kecamatan Kencong sebesar $79,0 \%$. Pengaruh tersebut bersifat positif yang berarti semakin tinggi pendapatan petani padi, maka pola konsumsi petani padi tersebut semakin beragam.
\end{abstract}

Kata Kunci: Pendapatan, Pola Konsumsi, Kelompok Tani

\section{PENDAHULUAN}

Indonesia merupakan negara agraris yang sebagian besar penduduknya bermata pencaharian sebagai petani. Sektor pertanian merupakan sektor yang bertanggung jawab menyediakan kebutuhan pangan masyarakat sehingga eksistensinya mutlak diperlukan. Sektor pertanian merupakan sektor yang menyediakan kesempatan kerja terbesar bagi tenaga kerja, dimana pada tahun 2017 sebesar 30\% dari seluruh angkatan kerja Indonesia bekerja di sektor pertanian.

Desa Wonorejo adalah salah satu desa di Kecamatan Kencong Kabupaten Jember yang sebagian besar rumah tangga bekerja sebagai petani padi, yakni sebesar 66,52\% atau sejumlah 2.397 rumah tangga (Kecamatan Kencong Dalam Angka, 2016). Sektor pertanian di desa Wonorejo berperan menyediakan bahan pangan pokok, kesempatan kerja, dan sumber pendapatan sebagian besar petani. Dengan luas tanam terbesar di Kecamatan Kencong yaitu 1.424 Ha diharapkan pendapatan yang diperoleh petani juga tinggi.

Hasil wawancara dengan beberapa anggota kelompok tani Ngudi Rejeki menunjukkan bahwa pendapatan yang mereka terima sangat variatif dan tidak menentu. Petani padi dengan luas tanam 1 Ha rata-rata memperoleh pendapatan sebesar Rp 20.000.000, itupun jika hasil panen baik. Namun petani pada kelompok tani Ngudi Rejeki rata-rata memiliki luas lahan 0,4 Ha. Dengan luas tanam tersebut, petani berharap dapat memperoleh pendapatan yang cukup untuk memenuhi kebutuhan hidup sehari-hari.

Banyak persoalan yang terjadi dalam sektor pertanian, antara lain pengetahuan dan kemampuan masyarakat yang masih rendah serta kepemilikan lahan yang sempit yaitu kurang dari 0,5 Ha sehingga dibutuhkan peranan dari pemerintah dalam hal ini pembentukan kelompok tani, dari kelompok tani inilah masyarakat petani akan diberdayakan sehingga produktivitas akan lebih efektif dan efisen. Pembinaan usahatani melalui kelompok tani tidak lain adalah sebagai upaya pencapaian tujuan bersama.

Majunya sistem pertanian tercermin pula besarnya pendapatan yang diterima dan pendapatan tersebut sebagian besar untuk keperluan konsumsi keluarga. Oleh karena itu sebagian besar petani di Desa Wonorejo bergabung dengan beberapa kelompok tani. Pembentukan kelompok tani telah dilakukan oleh petani di Desa Wonorejo sebagai media penyuluhan yang diharapkan lebih terarah dalam perubahan aktivitas usahatani yang lebih baik lagi. Aktivitas usahatani yang lebih baik dapat dilihat dari adanya peningkatan-peningkatan dalam 
produktivitas usahatani yang pada gilirannya akan meningkatkan pendapatan petani sehingga akan terpenuhi segala kebutuhan konsumsi keluarga.

Idealnya setiap keluarga ingin mempunyai pendapatan yang cukup besar sehingga semua kebutuhan hidup keluarga dapat tercukupi, dapat makan setiap hari, punya rumah yang layak, mendapat pendidikan secukupnya, dan bila ada anggota keluarga menderita sakit mendapat pemeliharaan dan pengobatan seperlunya. Namun, penggunaan pendapatan petani pada kelompok tani Ngudi Rejeki relatif diprioritaskan pada kebutuhan konsumsi makanan, pendidikan dan kesehatan.

Berdasarkan pemaparan di atas, maka penelitian ini bertujuan untuk mengetahui pengaruh pendapatan terhadap pola konsumsi petani padi pada kelompok tani Ngudi Rejeki Desa Wonorejo Kecamatan Kencong Kabupaten Jember.

\section{METODE}

Penelitian ini dilakukan pada tanggal 15 -20 Februari 2018. Responden dalam penelitian ini adalah petani yang tergabung dalam kelompok tani Ngudi Rejeki di Desa Wonorejo Kecamatan kencong Kabupaten Jember sebanyak 65 petani. Penelitian ini merupakan penelitian kuantitatif karena dalam prosedur dan analisisnya peneliti menggunakan metode statistik berupa angka-angka. Metode pengumpulan data yang digunakan terdiri dari metode angket, wawancara dan dokumen. Analisis data yang akan digunakan yaitu analisis inferensial (yang terdiri : analisis regresi linier sederhana, analisis varian garis regresi, efektivitas garis regresi/koefisien determinasi dan standart error of estimate).

\section{HASIL DAN PEMBAHASAN}

\section{Hasil Penelitian}

Analisis regresi linier sederhana digunakan untuk menguji pengaruh satu variabel bebas terhadap variabel terikat. Pengambilan keputusan dalam uji regresi linear sederhana dapat dilakukan dengan :

a. Membandingkan signifikasi dengan nilai probabilitas 0,05 . Jika nilai signifikansi $<0,05$, artinya variabel $X$ berpengaruh terhadap variabel Y dan sebaliknya.

b. Membandingkan nilai $t_{\text {hitung }}$ dengan $t_{\text {tabel }}$. Jika nilai $t_{\text {hitung }}>t_{\text {tabel }}$ maka variabel $X$ berpengaruh terhadap variabel $\mathrm{Y}$ dan sebaliknya.

Berikut output SPSS Versi 20.0 beserta penejalasannya:

$$
\text { Model Summary }
$$

\begin{tabular}{|l|r|r|r|r|}
\hline Model & $\mathrm{R}$ & R Square & $\begin{array}{c}\text { Adjusted R } \\
\text { Square }\end{array}$ & $\begin{array}{c}\text { Std. Error of } \\
\text { the Estimate }\end{array}$ \\
\hline 1 &, $889^{\mathrm{a}}$ &, 790 &, 786 & 4,30210 \\
\hline
\end{tabular}

a. Predictors: (Constant), Pendapatan

$$
\text { sumber : Hasiı srs. versi } \angle \mathrm{U.u}
$$

Tabel diatas menjelaskan besarnya nilai korelasi / hubungan (R) yaitu sebesar 0,889. Dari output tersebut diperoleh koefisien determinasi ( $\mathrm{R}$ square) sebesar 0,790 , yang mengandung pengertian bahwa pengaruh variabel bebas (pendapatan) terhadap variabel terikat (pola konsumsi) adalah sebesar 79,0\% .

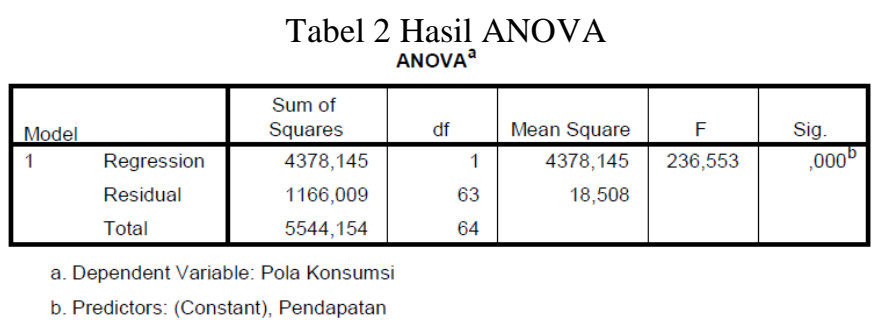

Sumber : Hasil SPSS Versi 20.0 
Tabel diatas menjelaskan bahwa nilai $\mathrm{F}$ hitung $=236,553$ dengan tingkat signifikansi sebesar $0,000<$ 0,05, maka model regresi dapat dipakai untuk memprediksi variabel pola konsumsi atau dengan kata lain ada pengaruh variabel pendapatan $(\mathrm{X})$ terhadap variabel pola konsumsi (Y).

Tabel 3 Hasil Coefficients

Coefficients $^{\mathrm{a}}$

\begin{tabular}{|c|c|c|c|c|c|c|}
\hline \multirow{2}{*}{\multicolumn{2}{|c|}{ Model }} & \multicolumn{2}{|c|}{ Unstandardized Coefficients } & \multirow{2}{*}{$\begin{array}{c}\text { Standardized } \\
\text { Coefficients }\end{array}$} & \multirow[b]{2}{*}{$t$} & \multirow[b]{2}{*}{ Sig. } \\
\hline & & $B$ & Std. Error & & & \\
\hline \multirow[t]{2}{*}{1} & (Constant) & 54,429 & 1,114 & & 48,879 &, 000 \\
\hline & Pendapatan & 9,395 & ,611 &, 889 & 15,380 &, 000 \\
\hline
\end{tabular}

a. Dependent Variable: Pola Konsumsi

Sumber : Hasil SPSS Versi 20.0

Berdasarkan hasil analisis diketahui bahwa $t_{\text {hitung }}$ sebesar 15,380 $>t_{\text {tabel }(0,05 ; 63)}$ sebesar 1,998, sehingga dapat disimpulkan bahwa variabel pendapatan (X) berpengaruh terhadap variabel pola konsumsi (Y). Pada tabel 4.12 juga dapat diketahui nilai Constant (a) sebesar 54,429, sedangkan nilai Pendapatan (b / koefisien regresi) sebesar 9,395, sehingga persamaan regresinya dapat ditulis :

$$
\begin{aligned}
& Y=a+b X \\
& Y=54,429+9,395 x
\end{aligned}
$$

Persamaan tersebut berarti :

1) Konstanta sebesar 54,429, mengandung arti bahwa nilai konsisten variabel pola konsumsi adalah sebesar 54,429

2) Koefisien regresi $X$ sebesar 8,714 menyatakan abhwa setiap penambahan $1 \%$ nilai pendapatan, maka nilai pola konsumsi bertambah sebesar 9,395. Koefisien regresi tersebut bernilai positif, sehingga dapat dikatakan bahwa arah pengaruh variabel $\mathrm{X}$ terhadap variabel $\mathrm{Y}$ adalah positif.

Sebelum persamaan tersebut digunakan untuk menarik kesimpulan terlebih dahulu dilakukan uji linieritas dan uji linieritas dan uji normalitas.

1) Uji Linieritas

Jika nilai Sig. Deviation from linierity > 0,05, maka terdapat hubungan yang linier antara variabel bebas dengan variabel terikat.

Tabel Error! No text of specified stvle in document. Hasil Uii Linieritas

\begin{tabular}{|c|c|c|c|c|c|c|c|}
\hline & & & $\begin{array}{l}\text { Sum of } \\
\text { Squares }\end{array}$ & df & Mean Square & $\mathrm{F}$ & Sig. \\
\hline \multirow{5}{*}{$\begin{array}{l}\text { Pola Konsumsi * } \\
\text { Pendapatan }\end{array}$} & \multirow[t]{3}{*}{ Between Groups } & (Combined) & 4461,576 & 3 & 1487,192 & 83,799 & .000 \\
\hline & & Linearity & 4378,145 & 1 & 4378,145 & 246,695 &, 000 \\
\hline & & Deviation from Linearity & 83,430 & 2 & 41,715 & 2,351 & , 104 \\
\hline & \multicolumn{2}{|l|}{ Within Groups } & 1082,578 & 61 & 17,747 & & \\
\hline & \multicolumn{2}{|l|}{ Total } & 5544,154 & 64 & & & \\
\hline
\end{tabular}
ANOVA Table

sumber: Hası sess vers1 LU.U

Berdasarkan hasil uji linieritas diketahui nilai Sig. Deviation from linierity sebesar 0,104 > 0,05, maka dapat disimpulkan bahwa terdapat hubungan yang linier antara pendapatan dengan pola konsumsi.

2) Uji Normalitas

Uji normalitas kolmogorov smirnov bertujuan untuk mengetahui apabila nilai residual berdistribusi normal atau tidak. Model regresi yang baik adalah memiliki nilai residual yang berdistribusi normal. Jika nilai Signifikan > 0,05 maka nilai residual berdistribusi normal dan sebaliknya.

Tabel 5 Hasil Uji Normalitas

One-Sample Kolmogorov-Smirnov Test

\begin{tabular}{|ll|r|}
\hline & & $\begin{array}{r}\text { Unstandardize } \\
\text { d Residual }\end{array}$ \\
\hline $\mathrm{N}$ & Mean & 65 \\
Normal Parameters & aE- $\mathrm{E}-7$ \\
Most Extreme Differences & Std. Deviation & 4,26835867 \\
& Absolute &, 084 \\
& Positive &, 084 \\
Kolmogorov-Smirnov Z & Negative &,- 053 \\
Asymp. Sig. (2-tailed) & &, 674 \\
\hline
\end{tabular}

a. Test distribution is Normal.

b. Calculated from data. 
Sumber : Hasil SPSS Versi 20.0

Berdasarkan hasil uji normalitas diketahui nilai signifikansi 0,754 > 0,05 maka dapat disimpulkan bahwa nilai residual berdistribusi normal.

a. Analisis Varian Garis Regresi

Analisis ini digunakan untuk mengetahui kuat tidaknya atau untuk mengetahui tingkat keeratan komponen pendapatan (X) terhadap pola konsumsi (Y). Berdasarkan perhitungan SPSS Versi 20 diketahui hasil sebagai berikut :

Tabel 6 Model Summary

Model Summary

\begin{tabular}{|l|c|r|r|r|}
\hline Model & $\mathrm{R}$ & $\mathrm{R}$ Square & $\begin{array}{c}\text { Adjusted R } \\
\text { Square }\end{array}$ & $\begin{array}{c}\text { Std. Error of } \\
\text { the Estimate }\end{array}$ \\
\hline 1 &, $889^{\mathrm{a}}$ &, 790 &, 786 & 4,30210 \\
\hline
\end{tabular}

a. Predictors: (Constant), Pendapatan

sumber : Hasil srs vers1 LU.U

Hasil analisis ini diperoleh melalui perhitungan menggunakan SPSS Versi 20.0 diketahui nilai multiple R yang menunjukkan korelasi atau hubungan antara variabel bebas dan variabel terikat yaitu sebesar 0,889. Koefisien korelasi sebesar 0,889 tersebut menunjukkan bahwa hubungan antara pendapatan (X) terhadap pola konsumsi (Y) dikategorikan mempunyai hubungan yang sangat kuat.

b. Uji F

Uji F digunakan untuk menguji hipotesis pertama, yaitu untuk mengetahui pengaruh variabel bebas (X) terhadap variabel terikat (Y). Uji ini dilakukan dengan membandingkan nilai $\mathrm{F}$ hitung dengan Ftabel. Berdasarkan perhitungan SPSS Versi 20.0 diketahui nilai Fhitung sebagai berikut :

Tabel 7 Rekapitulasi Hasil SPSS Untuk Uji F

\begin{tabular}{|c|c|c|c|c|}
\hline Variabel & $\mathrm{F}_{\text {hitung }}$ & $\mathrm{F}_{\text {tabel }}$ & $\mathrm{a}$ & Sig. F \\
\hline X terhadap Y & 236,553 & 3,99 & 0,05 & 0,000 \\
\hline
\end{tabular}

Sumber : Data primer yang diolah

Berdasarkan tabel diatas diketahui bahwa besarnya $F_{\text {hitung }}=236,553>F_{\text {tabel }}=3,99$ dengan tingkat Signifikansi $F=0,000<a=0,05$. Hal ini menunjukkan bahwa secara simultan pendapatan mempunyai pengaruh yang signifikan terhadap pola konsumsi. Berdasarkan tabel diatas dapat disimpulkan bahwa Ho ditolak dan Ha diterima yang berarti ada pengaruh yang signifikan dari pendapatan terhadap pola konsumsi petani padi pada Kelompok Tani Ngudi Rejeki di Desa Wonorejo Kecamatan Kencong.

c. Analisis Koefisien Determinasi

Berdasarkan hasil SPSS Versi 20.0 diperoleh nilai koefisien determinasi $\left(\mathrm{R}_{\text {square }}\right)$ sebesar 0,687. Rumus yang digunakan adalah sebagai berikut :

$$
\mathrm{R}_{\text {square }} \times 100 \%=0,790 \times 100 \%=79 \%
$$

Hal ini menunjukkan bahwa besarnya persentase pengaruh pendapatan terhadap pola konsumsi petani padi pada Kelompok Tani Ngudi Rejeki di Desa Wonorejo Kecamatan Kencong sebesar 79\% sedangkan sisanya yaitu $21 \%$ dipengaruhi variabel bebas lain yang tidak diteliti dalam penelitian ini seperti pendidikan, tempat tinggal dan iklim, agama/kepercayaan, umur, pekerjaan, harga barang dan kelas sosial.

\section{d. Standard Error Of Estimate}

Berdasarkan hasil SPSS bagian Model Summary menunjukkan bahwa Standard Error Of Estimate sebesar 4,30210. Hal tersebut menunjukkan besarnya penyimpangan variabel pendapatan terhadap garis regresinya sebesar 4,30210 . 


\section{Pembahasan}

Berdasarkan hasil penelitian yang dilakukan, baik dari hasil angket dan wawancara menunjukkan variabel pendapatan berpengaruh signifikan terhadap pola konsumsi petani padi pada kelompok tani Ngudi Rejeki di Desa Wonorejo Kecamatan Kencong. Besarnya persentase tersebut yakni 79\%. Pengaruh tersebut bersifat positif yang berarti semakin tinggi pendapatan petani padi, maka pola konsumsi petani padi tersebut semakin beragam.

Petani dengan pendapatan rendah akan mengkonsumsi makanan yang hampir sama setiap harinya. Sedangkan petani dengan pendapatan tinggi akan mengkonsumsi makanan yang lebih beragam dan bermacam. Hal tersebut sejalan dengan pendapat (Madanijah, 2004) yang menyatakan bahwa pada masyarakat yang tingkat ekonominya rendah, kebutuhan mereka akan pangan cenderung kurang dari kebutuhan makanan yang seharusnya sehingga pada masyarakat dengan tingkat ekonomi rendah, pola makan menjadi terbatas dan cenderung makanan yang dikonsumsi sama dan berulang setiap harinya, dalam artian tidak bervariasi.

Berdasarkan hasil analisis variabel pendapatan petani menunjukkan bahwa secara umum pendapatan keluarga petani padi memiliki pendapatan yang tergolong rendah. Dimana luas lahan yang dimiliki petani yakni rata-rata $0,4 \mathrm{Ha}$. Pendapatan bersih petani dapat diketahui dari pendapatan kotor dikurangi biaya-biaya. Menurut (Gustiyana, 2004) pendapatan petani adalah selisih antara pendapatan kotor (output) dan biaya produksi (input) yang dihitung dalam per bulan, per tahun, per musim tanam. Perbedaan pendapatan tersebut dikarenakan perbedaan luas lahan yang dimiliki. Semakin besar luas lahan yang dimiliki maka pendapatan petani semakin tinggi. Hal tersebut sesuai dengan pendapa (Phahlevi, 2013) bahwasanya faktor yang mempengaruhi pendapatan petani antara lain luas lahan, harga, biaya produksi, dan jumlah produksi. Berikut hasil wawancara dengan salah satu petani yang menjadi respoden dalam penelitian ini.

Pendapatan bersih yang saya peroleh dalam 1 petak sawah rata-rata sebesar Rp 4.000 .000 dengan total biaya rata-rata sebesar Rp 2.000 .000 jadi pendapatan bersih yang diperoleh petani dalam 1 petak sawah rata-rata Rp 2.000.000 per musin panen. Itu pendapatan jika mempunyai 1 petak sawah, kalau 3 petak berarti tinggal mengalikan saja. (D, 45 thn)

Pendapatan yang semakin tinggi tidak hanya berpengaruh pada konsumsi makanan. Petani dengan pendapatan rendah cenderung mengkonsumsi makanan pokok (beras) dari hasil panen dan lauk pauk seperti sayur, ikan dan telur. Ikan yang biasa dikonsumsi petani yaitu ikan benggol dan ikan tongkol. Sedangkan untuk konsumsi makanan petani pendapatan tinggi lebih sering mengkonsumsi lauk pauk seperti sayur, ikan tongkol, ikan benggol, ikan lele, ikan mujaer serta mengkonsumsi udang dan daging ayam.

Pendapatan bersih petani akan dibelanjakan untuk barang konsumsi, artinya barang yang dikonsumsi oleh petani memiliki pola atau kualitas dan kuantitas yang berbeda diantara petani. Misalnya ketika pendapatan petani rendah, maka beras yang dikonsumsi adalah kualitas yang kurang baik, akan tetapi setelah adanya penambahan pendapatan maka konsumsi beras menjadi kualitas yang lebih baik (Soekartawi, 2002).

Selain konsumsi makanan, konsumsi bukan makanan juga bertambah. Hasil penelitian menunjukkan setiap bertambahnya pendapatan yang diterima cenderung digunakan untuk pendidikan anak, berjaga-jaga untuk biaya kesehatan dan digunakan untuk investasi (pembelian tanah, pembelian kendaraan, dan lain-lain). Hal tersebut sejalan dengan yang dikatakan Soekartawi yaitu Semakin tinggi pendapatan, semakin banyak jumlah dan jenis benda maupun jasa yang dikonsumsi, dan sebaliknya makin sedikit pendapatan, makin berkurang jumlah benda maupun jasa yang dikonsumsi (Soekartawi, 2002).

Dilihat dari hasil wawancara, pengeluaran untuk pendidikan masing-masing petani berbeda. Tergantung dari tingkat pendidikan, kebutuhan pendidikan (buku, ATK, SPP/Infaq), jarak sekolah ke rumah (biaya transportasi), dan biaya diluar pendidikan (les/kursus). Tingkat pendidikan anak petani mempunyai ragam jenis mulai dari TK, SD, SMP, SMA bahkan hingga perguruan tinggi.

Anak saya yang pertama sudah lulus S2 dan anak ke dua saya masih duduk dibangku kelas 6 SD. Saya ingin anak kedua juga bisa mlanjutkan pendidikan seperti kakaknya hingga perguruan tinggi oleh karena pentingnya pendidikan untuk masa depan, anak saya yang kedua saya ikutkan les agar pengetahuannya selalu berkembang (S, 60 thn)

Hal lain juga disampaikan oleh salah satu petani yang menjadi responden yakni :

Saya mempunyai 2 anak, anak pertama saya kelas 5 SD dan kelas 3 MAN. Karena anak pertama saya 
sebentar lagi ujian, jadi saya suruh ikut bimbingan supaya hasil UN baik dan semoga bisa diterima di tempat kuliah yang diinginkan. (P, 45 thn)

Dalam hal pemenuhan kesehatan setiap petani memiliki cara yang berbeda. Beberapa petani lebih suka melakukan pengobatan dengan cara membeli jamu tradisional. Karena dirasa lebih alami dan membuat tubuh lebih segar dan sehat. Namun kebanyakan petani lebih suka melakukan pengobatan dengan cara membeli obat di toko/apotik, karena mereka merasa dengan membeli obat obat di toko/apotik harganya lebih murah dibandingkan harus periksa ke dokter/rumah sakit.

Namun beberapa petani lebih memilih melakukan pengobatan di rumah sakit jika dirasa rasa sakit sudah tidak bisa ditangani dengan hanya meminum jamu/obat. Karena pelayanan di rumah sakit tidak diragukan lagi. Hal tersebut dapat diketahui dari hasil wawancara dengan salah satu petani yang menjadi respoden dalam penelitian ini.

Saya lebih suka meminum jamu jawa, karena sudah terbiasa dan bisa membuat tubuh menjadi lebih segar dan sehat." (S, 60 thn)

Bulan kemarin anak saya mengalami sakit dan saya membawanya ke rumah sakit. Dan dokter mengatakan kalau anak saya terkena gangguan THT dan dibagian telinga harus dibersihkan. Total pengeluaran untuk pengobatan anak saya tersebut sekiatr Rp 500.000. (P, 45 thn)

Selain untuk pendidikan anak dan kesehatan, hasil panen tersebut juga digunakan untuk investasi (pembelian tanah, pembelian kedaraan, dan lain-lain). Menurut (Indrayani, 2016) para petani melakukan investasi, baik berjangka panjang maupun berjangka pendek, dan dengan demikian mereka melakukan baik investasi berisiko maupun investasi aman. Adapun alternatif investasi yang bisa dipilih oleh petani meliputi dalam bentuk anak, ternak, tanah, dan dalam bentuk benda milik pribadi atau benda milik keluarga. Berikut hasil wawancara dengan salah satu petani yang menjadi respoden dalam penelitian ini.

Kalau hasil lumayan bagus dan pendapatan lumayan banyak, saya lebih suka digunakan untuk pembelian tanah, jadi bisa digunakan untuk investasi di masa depan. Karena saya kesini ini merantau sudah sewajarnya kalau saya mengumpulkan investasi dalam bentuk tanah sebanyak-banyaknya. (A, 40 thn)

Beberapa petani juga menggunakan hasil panen untuk investasi dalam bentuk pembelian kendaraan. Berikut hasil wawancara dengan beberapa petani yang menjadi respoden dalam penelitian ini.

Saya memiliki 1 mobil dan 1 sepeda motor. Alhamdulillah jika hasil panen bagus dan hasilnya memuaskan saya bisa gunakan untuk nyelengi dan ahirnya bisa kami gunakan untuk membeli kendaran tersebut. (S, 60 thn)

Jadi dapat disimpulkan bahwa pola konsumsi baik makanan maupun bukan makanan antara petani dengan pendapatan rendah dan tinggi memiliki perbedaan. Petani lebih cenderung melakukan pola konsumsi makanan hal tersebut disebabkam karena rendahnya pendapatan yang mereka peroleh. Namun bagi petani yang berpendapatan tinggi lebih banyak digunakan untuk kebutuhan pendidikan anak dan melakukan investasi atau pembelian asset tetap seperti tanah dan kendaraan.

\section{PENUTUP}

Berdasarkan hasil penelitian mengenai pengaruh pendapatan terhadap pola konsumsi petani padi pada kelompok tani Ngudi Rejeki di Desa Wonorejo Kecamatan Kencong dapat disimpulkan bahwa ada pengaruh yang signifikan. Besarnya pengaruh pendapatan terhadap pola konsumsi yaitu $79 \%$ sedangkan sisanya dipengaruhi variabel lain yang tidak diteliti.

Berdasarkan hasil penelitian ini, maka peneliti dapat memberikan saran yaitu petani harus bisa lebih bijaksana dalam mengelola dan menggunakan pendapatan yang dimilikinya. Petani juga harus mampu mengendalikan diri dalam memenuhi kebutuhan konsumsi. Pihak kelompok pertanian juga harus lebih intensif dalam memberikan pelatihan keterampilan yang dapat dijadikan sebagai bekal dalam pengolahan lahan 
pertanian.

\section{DAFTAR PUSTAKA}

Gustiyana, H. 2004. Analisis Pendapatan Usahatani untuk Produk Pertanian. Salemba empat. Jakarta.

Indrayani, D. d. 2016. Pengantar Sosiologi Perdesaan. Jakarta: Kencana.

Madanijah. 2004. Pola Konsumsi Pangan. Jakarta: Penebar Swadaya.

Soekartawi. 2002. Faktor-Faktor Produksi. Jakarta: Salemba Empat.

Phahlevi, R. 2013. Faktor-Faktor Yang Mempengaruhi Pendapatan Petani Padi Sawah di Kota Padang Panjang. Skripsi. Universitas Negeri Padang. 